\title{
HUMAN RESOURCE DEVELOPMENT PRACTICES FOR ORGANIZATIONAL PERFORMANCE
}

\author{
I Wayan Gede Suharta Dewantara \\ Ph.D scholar, Post Graduate School of Economics \\ Hasanuddin University \\ South Sulawesi, Indonesia
}

Eka Afnan Troena

Professor of Economics, Post Graduate School of Economics

Brawijaya University

East Java, Indonesia

Siti Haerani

Professor of Economics, Post Graduate School of Economics

Hasanuddin University

South Sulawesi, Indonesia

Nurdjanah Hamid

Ph.D of Economics, Post Graduate School of Economics

Hasanuddin University

South Sulawesi, Indonesia

DOI: 10.31364/SCIRJ/v7.i12.2019.P1219730

http://dx.doi.org/10.31364/SCIRJ/v7.i12.2019.P1219730

\begin{abstract}
HRM practices are said to be effective if ongoing policies and practices can support the achievement of specific organizational goals. This study aims to analyze all dimensions of HRM practices consisting of job security, compensation, job autonomy, and supervisory support for organizational performance. This research is an explanatory study that examines each variable to obtain the results of the analysis of relationships between variables. This research was conducted in several group companies in South Sulawesi. The research design uses survey research methods. The population of this study was 4,784 organic employees, determining the number of samples using Slovin method, as many as 369 people. Primary data collection is obtained through a questionnaire. The analysis technique uses multiple linear regression analysis. The results showed that all dimensions of HRM practices (job security, compensation, job autonomy, and supervisory support) on organizational performance.
\end{abstract}

Index Terms - job security, compensation, job autonomy, supervisory support, and organizational performance

\section{INTRODUCTION}

HRM practices within the company can be effective by assessing a number of key factors including HR policies that can support HR goals and strategies, the applied linkages of HR policies and practices with results, the realization of improved employee performance, increased employee orientation to customers, and delegation the authority for decision making is effective (ÚbedaGarcía et al. 2018). HRM practices have a clear and very strong concept because they are related to strategic management, and human capital (Ahammad et al. 2019). HRM practices become strategic partners to help the success of the company's business strategy (Torre, 2019). By changing business strategies into HRM practices help a number of things in the business. First condition; businesses are able to adapt to changes because time from conception to strategy execution is shortened. Second condition; businesses can better 
meet consumer demand because customer service strategies can be translated into specific policies and practices. Third condition; businesses can achieve financial performance through the execution of more effective strategies (Şendoğdu et al. 2013).

Changes in the external environment can lead to a response to make changes to three things, the first change: changes in initiatives that focus on implementing new programs, projects or procedures such as implementing new organizational structures, and improving quality. The second change: process change, where the company focuses on how the work is done. The third change: adapting the culture, especially from the external, the new corporate cultural values are then transformed to employees. The role of $\mathrm{HR}$ is required to be more advanced by being actively involved directly in the strategic decision-making process, as a consequence of changing the current dynamic environment, by itself has created new challenges for organizations which, according to Ulrich (1997) there are several competitive challenges in the present and future, namely: (1) Globalization; (2) Competence and intellectual capital; (3) Profitability throught cost and growth; (4) Technology; (5) Capability focus; (6) Change, change ang change some more; (7) Value chains for business competitiveness and human resources services; and (8) Turnround is not transformation (Cheng \& Hackett, 2019).

Facing such rapid and dynamic uncertainty, the organization's long-term goals are highly dependent on management's response to internal and external challenges (Jaskiene, 2015), management's response is to face changes that occur with HR planning capable of anticipating future developments, basically HR planning is an anticipation process and makes provisions to regulate HR activities (Kianto et al. 2017). HR planning that is made must be integrated with the business strategy plan, both short and long term with several aspects, namely: the projected number of employees needed; identification of available HR in the organization; analysis of demand and supply balance; and action programs (Zubielqui et al. 2019).

Performance measurement is complex and is a big challenge for researchers (Lopez-Cabrales \& Valle-Cabrera, 2019) because of a performance construct that is multidimensional and therefore performance measurement with a single measurement dimension is unable to provide a comprehensive understanding (Podgorodnichenko et al. 2019). Performance measurement should use or integrate diverse measurements (Horwitz, 2017). This study aims to analyze the effect of job security, compensation, job autonomy, and supervisory support on organizational performance.

\section{LITERATURE REVIEW}

\subsection{HRM practices}

There has been a shift in the role of the HR manager in the organization, initially functionally the HR manager only managed personnel administration, operational and transactional (Russell et al. 2018). But the role of HR is increasingly changing in the present perspective. The roles of human resources from time to time increasingly have a strategic place in business activities. Some HR experts propose these roles as the new role of HR (Podolsky, 2018) related to organizational strategy. The new role of HR occurs because of environmental changes that create new challenges for the organization. Technological advances provide opportunities for HR managers and line managers to become important players in the management team (Allen et al. 2018), and now even become strategic partners to determine the direction of policy in the company.

The implementation of the role of human resources is important to be communicated and developed continuously in order to improve their skills, knowledge and abilities (Kesti, 2012). Furthermore, they can integrate the role of human resources into the framework and diagnostic tools used in career planning, succession, selection and development of human resources, and into the entire system of organizations. Various changes that occur, such as changes from operational problems to strategic, quantitative to qualitative, regulating cooperation, short-term to long-term, administrative to consultative, functional orientation to business orientation, internal focus to external focus / customer, reactive to be proactive, the focus of activity becomes the focus of solving. HRM practices as a set of practices used by companies to manage employees through facilitating the development of competencies based on company specifications to produce complex social relationships and generate knowledge to maintain competitive advantage, with dimensions as follows (Meyer \& Smith, 2000): (a) Job Security; (b) Compensation; (c) Job Autonomy; and (d) Supervisory Support.

\subsection{Organizational performance}

Organizational performance can be seen and who needs assessment, for management to see the contribution that can be made by a particular part of achieving overall goals (Abubakar et al. 2019). Whereas from outside the performance management is a tool to measure an achievement achieved by an organization in a certain period which is a reflection of the level of results of the implementation of its activity activities. Organizational performance is an achievement that has been achieved by the company in the operational field of an organization, as well as existing resources based on targets, standards, and criteria that have been predetermined in a certain period that reflects the company's health level in a particular field (Maletič et al. 2018; Jiang \& Holburn, 2018; \& Ali et al. 2018). 
Samad (2012) argues that organizational performance is the actual achievement of the organization compared to the expected performance of the organization. Expected work performance is a standard achievement that is arranged as a reference so that it can see the organization's performance compared to the standards planned. According to Jin et al. (2019) that performance as a collection of work results according to quantity, quality, efficiency and effectiveness of work in achieving goals. Performance measurement is a formal effort carried out systematically by management in evaluating the results achieved by utilizing the resources owned by the company efficiently and effectively in a period to achieve the goals or mission set by the company.

\section{RESEARCH METHODS}

This study aims to test and analyze the factors that influence organizational performance, namely job security, compensation, job autonomy, and supervisory support as exogeneus variables and organizational performance as variable endegoneus. This group of companies in South Sulawesi. The research design uses survey research methods. The population of this study was 4,784 organic employees, the number of samples using Slovin method, as many as 369 people. We provide questionnaires to respondents who have met the criteria for the study sample. This questionnaire is arranged in the form of written questions given to respondents. The analysis technique uses multiple linear regression analysis.

\section{RESULTS AND DISCUSSION}

\subsection{Research Instrument Testing Results}

The results of the analysis of the validity of the research instruments (job security, compensation, job autonomy, supervisory support and organizational performance) are presented in the following table.

Table 1

Validity and Reliability Test Results of All Construct

\begin{tabular}{|c|c|c|c|c|c|}
\hline Variables & $\begin{array}{l}\text { Alpha } \\
\text { Cronbach }\end{array}$ & Information & Symbols & $\begin{array}{l}\text { Corrected } \\
\text { Item-Total } \\
\text { Correlation }\end{array}$ & Information \\
\hline \multirow{4}{*}{ Job security } & \multirow{4}{*}{0.834} & \multirow{4}{*}{ Reliability } & $\mathrm{X} 11$ & 0.824 & \multirow{4}{*}{ Valid } \\
\hline & & & $\mathrm{X} 12$ & 0.826 & \\
\hline & & & $\mathrm{X} 13$ & 0.828 & \\
\hline & & & $\mathrm{X} 21$ & 0.823 & \\
\hline \multirow[t]{2}{*}{ Compensation } & \multirow[t]{2}{*}{0.862} & \multirow[t]{2}{*}{ Reliability } & $\mathrm{X} 22$ & 0.825 & \multirow[t]{2}{*}{ Valid } \\
\hline & & & $\mathrm{X} 23$ & 0.832 & \\
\hline \multirow{3}{*}{ Job autonomy } & \multirow{3}{*}{0.846} & \multirow{4}{*}{ Reliability } & X31 & 0.831 & \multirow{3}{*}{ Valid } \\
\hline & & & $\mathrm{X} 32$ & 0.830 & \\
\hline & & & $\mathrm{X} 33$ & 0.832 & \\
\hline \multirow{3}{*}{ Supervisory support } & \multirow{3}{*}{0.924} & & $\mathrm{X} 41$ & 0.825 & \multirow{3}{*}{ Valid } \\
\hline & & \multirow[t]{2}{*}{ Reliability } & $\mathrm{X} 42$ & 0.826 & \\
\hline & & & $\mathrm{X} 43$ & 0.823 & \\
\hline \multirow{5}{*}{$\begin{array}{l}\text { Organizational } \\
\text { performance }\end{array}$} & \multirow{5}{*}{0.916} & \multirow{5}{*}{ Reliability } & Y11 & 0.848 & \multirow{5}{*}{ Valid } \\
\hline & & & Y12 & 0.854 & \\
\hline & & & Y13 & 0.845 & \\
\hline & & & Y14 & 0.855 & \\
\hline & & & Y15 & 0.853 & \\
\hline
\end{tabular}

Reliability testing is done on indicators (items or observable variables or criterions) that measure (factor or variable or predictor). This is done because variables are not measured directly, but are measured through indicators from each construct. Based on the results of the analysis it was stated that statistically the data collection instruments used in this study were valid and reliable.

\subsection{Results of the Multiple Linear Regression Analysis}


Multiple regression is used to determine the level of influence of job security, compensation, job autonomy, and supervisory variables on organizational performance. The results of the calculation of multiple regression models will be obtained estimation parameters with t-count values and coefficient of determination (R square). If the regression coefficient is significant on probability 5 0.05 , the independent variables (job security, compensation, job autonomy, and supervisory support) have a significant influence on the dependent variable (organizational performance). The results of the calculation of multiple regression models using SPSS 20.0 software show the following results:

Table 2

Results of Analysis of Regression

\begin{tabular}{lllll}
\hline \multicolumn{1}{c}{ Variables } & $\begin{array}{c}\text { Unstandardized } \\
\text { Coefficients }\end{array}$ & T value & p-value & Information \\
\hline Constant & 1.120 & 3.198 & 0.002 & Significant \\
Job security & 0.092 & 2.095 & 0.038 & Significant \\
Compensation & 0.106 & 2.045 & 0.043 & Significant \\
Job autonomy & 0.240 & 2.486 & 0.014 & Significant \\
Supervisory support & 0.273 & 2.939 & 0.004 & Significant \\
\hline
\end{tabular}

The regression coefficient of job security variables is 0.092 . The coefficient relates to a positive and significant relationship between job security variables on organizational performance. Thus, improving the quality of job security will increase in improving organizational performance. The compensation variable regression coefficient is 0.106 . The coefficient is a positive and significant contribution between the compensation variables on organizational performance. Thus, increasing the quality of compensation will increase in improving organizational performance. Job autonomy variable regression coefficient of 0.240 . The coefficient indicates a positive and significant relationship between job autonomy variables on organizational performance. Thus, improving the quality of job autonomy will have an impact on improving organizational performance. The supervisory support variable regression coefficient is 0.273 . The coefficient indicates a positive and significant relationship between supervisory support variables for organizational performance. Thus, improving the quality of supervisory support will have an impact on improving organizational performance.

The value of the job security variable $p$-value is 0.038 , this value is smaller than $\alpha=0.05$. This indicates a positive and significant influence between job security variables on organizational performance. Increasing organizational performance is determined by improving the quality of job security. These results prove that the first hypothesis was declared accepted. The value of the compensation variable $\mathrm{p}$-value is 0.043 , this value is smaller than $\alpha=0.05$. This indicates a positive and significant influence between compensation variables on organizational performance. Increasing organizational performance is determined by improving the quality of compensation. These results prove that the second hypothesis was declared accepted. The value of the job autonomy variable $\mathrm{p}$-value is 0.014 , this value is smaller than $\alpha=0.05$. This indicates a positive and significant influence between job autonomy variables on organizational performance. Increasing organizational performance is determined by improving the quality of job autonomy. These results prove that the third hypothesis was declared accepted. The value of the supervisory support variable p-value is 0.004 , this value is smaller than $\alpha=0.05$. This indicates a positive and significant influence between supervisory support variables on organizational performance. Increasing organizational performance is determined by improving the quality of supervisory support. These results prove that the fourth hypothesis was declared accepted.

\section{CONCLUDING REMARKS}

Job security, compensation, job autonomy, and supervisory support influence the increase in organizational performance by assuming other factors that influence organizational performance are considered constant. The magnitude of the coefficient value of the variables job security, compensation, job autonomy, and supervisory support for organizational performance reflects the high contribution of exogenous variables in determining the high organizational performance. It is important to improve the quality of HRM practices on organizational performance by evaluating compensation variables.

\section{REFERENCES}

[1] Abubakar, A.M., Hamzah Elrehail., Maher A. Alatailat., \& A. Elçi. (2019). Knowledge management, decision-making style and organizational performance. Journal of Innovation \& Knowledge, Vol. 4, Issue 2, pp: 104-114.

[2] Ahammad, M. F., Keith W. Glaister., \& E. Gomes. (2019). Strategic agility and human resource management. Human Resource Management Review, 24 July 2019. 
[3] Ali, M., Shen Lei., Xiao-Yong Wei. (2018). The mediating role of the employee relations climate in the relationship between strategic HRM and organizational performance in Chinese banks. Journal of Innovation \& Knowledge, Vol. 3, Issue 3, pp: 115122.

[4] Allen, S., P. Williams., \& D. Allen. (2018). Human resource professionals' competencies for pluralistic workplaces. The International Journal of Management Education, Vol. 16, Issue 2, pp: 309-320.

[5] Cheng, M.M., \& R.D. Hackett. (2019). A critical review of algorithms in HRM: Definition, theory, and practice. Human Resource Management Review, 21 June 2019.

[6] Horwitz, F. (2017). International HRM in South African multinational companies. Journal of International Management, Vol. 23, Issue 2, pp: 208-222.

[7] Jaskiene, J. (2015). HRM Practices Enhancing Research Performance. Procedia - Social and Behavioral Sciences, Vol. 213, pp: 775-780.

[8] Jiang, G.F., \& Guy L.F. Holburn. (2018). Organizational performance feedback effects and international expansion. Journal of Business Research, Vol. 90, pp: 48-58.

[9] Jin, Yao Henry., S.E. Fawcett., A.D. Fawcett., \& D. Swanson. (2019). Collaborative capability and organizational performance: Assessing strategic choice and purity. International Journal of Production Economics, Vol. 214, pp: 139-150.

[10] Kesti, M. (2012). Organization human resources development connection to business performance. 2nd Annual International Conference on Qualitative and Quantitative Economics Research (QQE 2012), Procedia Economics and Finance, 2, pp: 257264.

[11] Kianto, A., J. Sáenz., \& N. Aramburu. (2017). Knowledge-based human resource management practices, intellectual capital and innovation. Journal of Business Research, Vol. 81, pp: 11-20.

[12] Lopez-Cabrales, A., \& R. Valle-Cabrera (2019). Sustainable HRM strategies and employment relationships as drivers of the triple bottom line. Human Resources Management Review, 20 May 2019.

[13] Maletič, M., D. Maletič., \& B. Gomišček. (2018). The role of contingency factors on the relationship between sustainability practices and organizational performance. Journal of Cleaner Production, Vol. 171, pp: 423-433.

[14] Meyer, P.J., \& Smith, A.C. (2000). HRM Practices and Organizational Commitment: Test of a Mediation Model. Canadian Journal of Administrative Sciences, 17, pp: 319-331.

[15] Podgorodnichenko, N., F. Edgar., \& Ian McAndrew. (2019). The role of HRM in developing sustainable organizations: Contemporary challenges and contradictions. Human Resources Management Review, 18 April 2019.

[16] Podolsky, M. (2018). The process of strategic work modeling:: Drawing clear connections between organization strategy and human resource management practices. Organizational Dynamics, Vol. 47, Issue 1, pp: 17-24.

[17] Russell, Z.A., D.S. Steffensen., B. Parker Ellen III., L. Zhang., J.D. Bishoff., \& G.R. Ferris. (2018). High performance work practice implementation and employee impressions of line manager leadership, Human Resource Management Review, Vol. 28, Issue 3, pp: 258-270.

[18] Samad, S. (2012). The Influence of Innovation and Transformational Leadership on Organizational Performance. Procedia Social and Behavioral Sciences, Vol. 57, pp: 486-493.

[19] Şendoğdu, A.A., A. Kocabacak., \& S. Güven. (2013). The Relationship between Human Resource Management Practices and Organizational Commitment: A Field Study. Procedia - Social and Behavioral Sciences, Vol. 99, pp: 818-827.

[20] Torre, E.D. (2019). Collective voice mechanisms, HRM practices and organizational performance in Italian manufacturing firms. European Management Journal, VOl. 37, Issue 3, pp: 398-410.

[21] Úbeda-García, M., E. Claver-Cortés., B. Marco-Lajara., P. Zaragoza-Sáez., \& F. García-Lillo. (2018) High performance work system and performance: Opening the black box through the organizational ambidexterity and human resource flexibility. Journal of Business Research, Vol. 88, pp: 397-406.

[22] Ulrich, D. (1997). Human Resource Champions. Harvard Business School Press, Boston, Mass.

[23] Zubielqui, G.C. de., H. Fryges., \& J. Jones. (2019). Social media, open innovation \& HRM: Implications for performance. Technological Forecasting and Social Change, Vol. 144, pp: 334-347. 